\title{
CHEMICAL COMPOSITION OF THE ESSENTIAL OIL AND FLAVONOIDS OF THYMUS SERPYLLUM L., GROWING ON TERRITORY OF THE EAST KAZAKHSTAN
}

\author{
KULYASH TAZABAYEVA* and BATIYASH SYLIBAYEVA \\ Department of Applied Biology, Kazakh Humanitarian Law Innovative University, \\ Semey, Kazakhstan
}

\begin{abstract}
Thymus serpyllum L. (T. serpyllum) has a great interest as a potential plant component, which is used in the production of fermented milk products with anticancer effect. The plant material was collected at the flowering stage. Chemical composition of essential oil and flavonoids from the aerial parts of the T. serpyllum, grown in the Southern Altai of the East Kazakhstan region, has been investigated for the first time. Output of the essential oil received from the aerial part of the plant in the flowering stage was on average $0.2 \%$. Fortyone compounds were identified in T. serpyllum essential oil, which accounts for $96.1 \%$ of the total oil. The main components of the oil were thymol $(41.8 \%)$, $\beta$-terpinene $(15.3 \%)$, o-cymene $(10.9 \%)$. Apart from the composition of essential oils, there were shown some flavonoids, such as apigenin-7-glucoside $(0.24 \%$ of dried plant material), luteolin $(0.039 \%)$, quercetin $(0.006 \%)$, which demonstrated a cytotoxic effect on cancer cells. In our experiments, luteolin had greater cytotoxic effect on cancer cells HCT-15 than quercetin. $\mathrm{IC}_{50}$ value of quercetin $(100 \mu \mathrm{M})$ was higher than that of luteolin $(50 \mu \mathrm{M})$.
\end{abstract}

Keywords: Thymus serpyllum, essential oils, flavonoids, anticancer activity

T. serpyllum - perennial, creeping shrub of the Labiatae family, height is $12-13 \mathrm{~cm}$ with thin prostrate trunks, which are ended with lying fruitless bine (1). It grows mainly in pine forests on sandy and podzolic soils of Northern and Central Europe, Russian Federation (on the territory of Siberia, Far East, and Caucasus) and Kazakhstan.

Its aerial parts are commonly used in ethnomedicine mainly for the treatment of diseases and problems related to the respiratory and digestive systems (2). Besides, it is used in ethnomedicine as an antiseptic, expectorant agent, antispasmodic and carminative substance (3).

In addition, thyme is used in diseases of kidney pelvis, bladder, insomnia, headaches, asthma, diseases of the joints, paralysis, women's diseases, infestation of tapeworms and is used as a diuretic, diaphoretic agent. Currently, thyme is extensively used as a spice in cooking due to its essential oils that have a strong pleasant smell.

Essential oil is a complex of volatile organic compounds of secondary metabolism, having a distinctive smell and taste, which are insoluble in water. One of the important peculiarities of the secondary metabolites is their relatively low molecular weight and the fact, that they are biologically active substances. These peculiarities are especially attractive for studying phytotherapeutic (antimicrobial, antioxidant and anticancer) properties of essential oils.

So, for example, in the research of Polish scientists the essential oil of the T. serpyllum showed a high antimicrobial activity against colon bacillus E. coli $($ minimum inhibitory concentrations $(\mathrm{MIC})=$ $0.025 \mu \mathrm{L} / \mathrm{mL}$ ) and fungi Candida albicans (MIC = $0.05 \mu \mathrm{L} / \mathrm{mL}$ ) (4).

Kindl M. et al. investigated the antioxidant properties of alcoholic extracts of 6 types of plants, such as Thymus - T. longicaulis, T. praecox, T. pulegioides, T. serpyllum, T. striatus, and T. vulgaris, growing in Croatia (5). Extracts of all types of thymus showed high regenerative capability, what is more, regenerative ability of $T$. serpyllum extract, was almost 2 times higher than pure luteolin and it was comparable with the antioxidant property of Trolox (model antioxidant).

* Corresponding author: e-mail: kultazab@mail.ru 
The joint research of Serbian, Portuguese and Latvian scientists there was conducted a comparative analysis of antimicrobial, antioxidant and anticancer properties of the three types of a plant of the genus Thymus: T. serpyllum, T. algeriensis, and T. vulgaris. Antimicrobial activity of the plants of the genus Thymus was tested on Streptococcus mutans, Streptococcus sanguis, Streptococcus pyogenes, Staphylococcus aureus, Pseudomonas aeruginosa, and Lactobacillus sp. Essential oils of all three types of Thymus expressed the significant antimicrobial activity with reference to all tested strains, though T. serpyllum was the most effective (MIC = 2.5-5 $\mu \mathrm{g} / \mathrm{mL} ; \mathrm{MBC}=10.5 \mu \mathrm{g} / \mathrm{mL}$ ) (6).

In this work, the antitumor activity of essential oils of the plant was tested on cell lines of five cancer types: MCF-7 (breast adenocarcinoma), NCIH460 (non-small cell lung cancer), HCT-15 (colon carcinoma), HeLa (cervical carcinoma), and HepG2 (hepatocellular carcinoma). Essential oils of all three types of Thymus showed a cytotoxic effect on the cells of all types of cancer. However, T. serpyllum showed the highest cytotoxic effect $\left(\mathrm{IC}_{50}=\right.$ 7.02-52.69 $\mu \mathrm{g} / \mathrm{mL}$ ), and the lowest $-T$. vulgaris $\left(\mathrm{IC}_{50}=76.02-180.40 \mu \mathrm{g} / \mathrm{mL}\right)$.

Antioxidant activity was defined by DPPH recovery (2, 2-diphenyl-1-picrylhydrazyl). The highest antioxidant activity was shown by essential oil of $T$. serpyllum $\left(\mathrm{EC}_{50}=0.96 \mu \mathrm{g} / \mathrm{mL}\right)$, and the lowest by $-T$. vulgaris $\left(\mathrm{EC}_{50}=4.80 \mu \mathrm{g} / \mathrm{mL}\right)(6)$. Differences in the antioxidant, antimicrobial and anticancer properties of essential oils of the various types of thyme, presumably due to varied qualitative and quantitative chemical composition of oils.

Accurately, this work illustrated, that the major constituent of the $T$. serpyllum oil was thymol $(56.02 \%)$, followed by carvacrol $(14.00 \%)$ and $\mathrm{p}$ cymene $(6.27 \%)$. Thymol was also a basic component in T. algreriensis essential oil (38.50\%) followed by p-cymene, terpinene and bornyl acetate and borneol $(8.91 \%, 7.19 \%, 7.03 \%$, and $6.07 \%$, respectively). Moreover, thymol in T. vulgaris is also a major constituent element with p-cymene (20.01\%) (6).

It is interesting that the chemical composition of the essential oils is different even being types of one plant $-T$. serpyllum but different subspecies T. serpyllum and T. serpyllum 'Aureus', and accordingly, various degree of antimicrobial activity. The essential oil obtained from T. serpyllum showed the highest antimicrobial activity relative to the strain of E. coli $(\mathrm{MIC}=0.025 \mathrm{mu} \mathrm{L} / \mathrm{mL})$ and to the yeast C. albicans (MIC $=0.05 \mathrm{mu} \mathrm{L} / \mathrm{mL}$ ) (4).

However, as it is known, the composition of essential oils depends on not only types of one plant genus, but also on geographic growing region, the stages of plant growth, collecting season, habitats and climate conditions. So, for example, in the research of Wesolowska et al. it has been found that essential oil of $T$. serpyllum from North-Western Poland consists of 47 compounds $(99.67 \%$ of the total value of essential oils). Among them, the main components were carvacrol $(37.49 \%), \gamma$-terpinene $(10.79 \%), \quad \beta$-caryophyllene $(6.51 \%)$, cymene $(6.06 \%),(\mathrm{E})$ - $\beta$-ocimene $(4.63 \%)$ and $\beta$-bisabolene $(4.51 \%)$ (4). In the essential oil of T. serpyllum growing in Romania, the main compound was determined as carvacrol $(25.8 \%)$, whereas, in the essential oil of other species of Thymus (T. vulgaris and T. pulegioides) main compound of the essential oil was thymol $(32.2 \%$ and $27.4 \%$, respectively) and terpinyl acetate $(47.6 \%)$ in $T$. glabrescent oil (7).

The content of essential oils in T. serpyllum of the western Baikal region, collected in the different phases of phenological growth also was different, its maximum concentration observed in the flowering phase $(0.49 \%)$ and the lowest - in the fruiting phase $(0.30 \%)(8)$.

Thus, currently, there are a number of studies showing the antioxidant, antimicrobial and antitumor actions of creeping thyme, the effectiveness of which may depend on the chemical composition of its essential oils.

However, in literature there are no data on the chemical composition of the essential oil and flavonoids of Thymus serpyllum L., growing on the territory of East Kazakhstan.

In addition, the plant resources of Thymus serpyllum L. in East Kazakhstan allow its use for the cancer therapy in humans.

In this regard, our main goal was to characterize the chemical composition of the essential oil and flavonoids of Thymus serpyllum L. growing in East Kazakhstan to further its use in functional dairy products with antitumor activity.

Our research was supported by the Ministry of Education and Science of the Republic of Kazakhstan under National applied Research Project "Development of biotechnological methods of application of medicinal plants with antitumor effect in the production of fermented dairy products" (UA4/3028).

\section{EXPERIMENTAL}

\section{Materials \\ Collection of plant material}

The aerial parts of $T$. serpyllum L. were collected at a full flowering stage, from wild plants in the 
mountains of Tarbagatay Mountains, Southern Altai of the East Kazakhstan region. Identification of the T. serpyllum L. was made with the use of the key to plants "Kazakhstan Flora" (9). The aerial parts of the plants were dried by the air-shadow method.

\section{Isolation of essential oils}

For T. serpyllum L. essential oils preparation, the dried aerial parts (leaves, stems, and flowers) (100 g) were hydrodistilled for 2-2.5 h utilizing an all-glass Clevenger-type apparatus in accordance with the method outlined by the Pharmacopeia (10). Chemically pure hexane has used as an essential oil trap. The intensity of the distillation should not exceed 45-50 drops per min. The yield of essential oils was on average $0.2 \%$.

\section{Determination of an essential oil composition}

Determination of the essential oil components was performed on a Clarus-SQ 8 gas chromatograph (PerkinElmer) with mass spectrometric detector.

\section{Preparing for taking the essential oil sample}

Nearly $25 \mathrm{mg}$ (accurate weight) of essential oil was placed into the volumetric flask with a capacity of $25 \mathrm{~mL}$, dissolved in $15 \mathrm{~mL}$ of hexane, carried to the established mark and mixed until getting the complete oil mixture.

\section{The chromatographic conditions}

Capillary column RestekRxi®-1 MS (30 m x $0.25 \mathrm{~mm}$ x $0.25 \mu \mathrm{m})$; sample volume - $1.0 \mathrm{~L}$; carrier gas - helium; the carrier gas speed $-1 \mathrm{~mL} / \mathrm{min}$; flow division $-1: 25$; column temperature -313.15 $\mathrm{K}$; growth $-275.15 \mathrm{~K} / \mathrm{min}$ to $553.15 \mathrm{~K}$; temperature of the evaporator $-553.15 \mathrm{~K}$; mass spectrometer temperature $-513.15 \mathrm{~K}$; the energy of ionizing electrons - $70 \mathrm{eB}$; scanning time - from 4 to $120 \mathrm{~min}$; ion scanning mode $-39-500 \mathrm{~m} / \mathrm{z}$. The percentage of essential oil components was calculated automatically, on the assumption of the peak areas of the total ions chromatogram. The components were identified by mass spectrum and retention times, using NIST library.

\section{Determination of the flavonoids}

The total contents of flavonoids in the ethanol extracts of T. serpyllum were estimated spectrophotometrically on UviLine 9100 (SI Analytics Germany) at a wavelength of $410 \mathrm{~nm}$ in the cuvette of $10 \mathrm{~mm}$ thick. Analysis of the content of flavonoids was conducted by (HPLC) with the use of a chromatograph Agilent 1290 Infinity. The separation was carried out in a gradient mode on a column ZORBAX RRHD STABLEBOND SB-C18 $1.8 \mu \mathrm{m}, 100 \times 2.1 \mathrm{~mm}$. The moving phase consisted of $0.1 \%$ of an aqueous solution of formic acid and acetonitrile, containing formic acid at the concentration of $0.1 \%$.

The gradient was carried out in the following continuity: source element was consisted of formic acid solution. Within five minutes, the concentration of acetonitrile was increased to $10 \%$ and remained the following five minutes. From sixth to the twentyfifth $\mathrm{min}$, the acetonitrile concentration was increased to $35 \%$. On the twenty-fifth to the thirtyseventh minute, the acetonitrile concentration was increased to $74 \%$. Then the column was cleaned and air-conditioned. Flow speed was equal to 0.3 $\mathrm{mL} / \mathrm{min}$ at $30^{\circ} \mathrm{C} .3 \mu \mathrm{L}$ samples were used for the analysis. Diode-array detector (DAD) at 280 and 325 $\mathrm{nm}$ carried registration. The absorption spectrum was fixed in the range of $200-450 \mathrm{~nm}$ with the step of two $\mathrm{nm}$. Identification of flavonoids was carried out in accordance with the retention time and absorption spectrum of appropriate analytical standards.

Quantitative assessment of flavonoids was held with the use of calibration by appropriate standard samples in the concentration range of $0.05-100 \mathrm{mg} / \mathrm{L}$.

\section{Determination of the flavonoids anticancer toxity}

The growth of HCT-15 cells was maintained with growth medium RPMI-1640 containing $2 \mathrm{mM}$ L-glutamine, $10 \%$ fetal serum, $100 \mathrm{U} / \mathrm{mL}$ penicillin, $100 \mu \mathrm{g} / \mathrm{mL}$ streptomycin and $5 \%$ carbon dioxide in an incubator at $37^{\circ} \mathrm{C}$. To investigate the cytotoxic effects on cancer cells thymol, apigenin, luteolin, and quercetin were dissolved in dimethyl sulfoxide and added to the suspension of cancer cells (200000 cells in $1 \mathrm{~mL}$ ). HCT-15 cells were treated with four source components in various concentrations for $24 \mathrm{~h}$. The viability of cancer cells was determined spectrophotometrically using the MTT assay. MTT test is the simplest cytotoxicity analysis of substances, and it is especially popular in experimental pharmacological studies (11).

\section{RESULTS AND DISCUSSION}

T. serpyllum L. was collected at the full flowering stage in the Tarbagatay Mountains, Southern Altai of the East Kazakhstan region.

Tarbagatay Mountains are not very tall. Their average height above sea level is $2000-2100 \mathrm{~m}$. The climate is continental. T. serpyllum L. was selected for the study as a potential herbal object for the use in manufacture of fermented dairy products with antitumor effect. 
A number of research works showed the antitumor activity of the T. serpyllum extract. For example, $T$. serpyllum extracts had high cytotoxicity in human breast cancer cell lines: adriamycin-resistant MCF-7/Adr and wild-type MCF-7/wt. (12), breast cancer cells (MCF-7 and MDA-MB-231) (12) and in human Jurkat cells (13).

Moreover, the extracts obtained from T. serpyllum showed the highest antioxidant and antimicrobial activity, related to the strains of $S$. aureus, $S$. epidermidis, K. pneumoniae, E. coli (15), L. monocytogenes, $S$. aureus, C. albicans (16) and to the yeast $C$. albicans $\left(\mathrm{IC}_{50}=0.05 \mu \mathrm{L} / \mathrm{mL}\right)(4)$.

\section{Chemical composition of the T. serpyllum essential oil}

The essential oils isolated by hydrodistillation from the aerial parts of $T$. serpyllum were found to be yellow liquids and were obtained with a yield of $2 \%$ based on the dry weight of plant material.

Medicinal properties of plants are determined by the presence of biologically active substances: essential oils, flavonoids, tannins, and others. Analysis of the chemical composition of the essential oils obtained by hydrodistillation from the aerial parts of T. serpyllum revealed the presence of 41 components, which are $96.1 \%$ of the total essential oil (Fig. 1 and Table 1).

As it is demonstrated in Table 1, the most of the essential oil components are acyclic and cyclic monoterpenoids $(61 \%)$, the smaller part are sesquiterpenoids (27\%) and a carboxylic acid and aldehyde $(2 \%)$. The main components, which were found in the oil, were thymol $(41.8 \%), \gamma$-terpinene $(15.3 \%)$, o-cymene $(10.9 \%)$.

These data are consistent with the results on chemical composition of the essential oil of thyme, collected in the State National Natural Park «Kokshetau» (Northern Kazakhstan). The main components of oil were thymol (5.11-58.25\%), carvacrol $(1.22-55.85 \%), p$-cymene $(1.28-25.46 \%), \gamma$ terpinene (1.37-16.52\%) and á-terpinene (0.84$1.94 \%)$ out of total twenty-one identified compounds (17).
However, in some literature data, the composition of essential oils of thyme was somewhat different. So, for example, the main components of the essential oil of thyme (growing in Estonia) were (E)nerolidol $(24.87 \%)$ and caryophyllene oxide (11.29\%) (18). According to the work of Polish researchers, the main components found in the $T$. serpyllum oil were carvacrol $(37.49 \%), \gamma$-terpinene $(10.79 \%), \beta$-caryophyllene $(6.51 \%)$, p-cymene $(6.06 \%)$, (E)-beta-ocimene $(4.63 \%)$ and beta-bisabolene (4.51\%) (4).

Nikolić M. et al. have shown that the main components in the essential oil of T. serpyllum were thymol $(56.02 \%)$, followed by carvacrol $(14.00 \%)$ and p-cymene $(6.27 \%)$ (6). Apparently, the above differences in the chemical composition of essential oils of thyme, as was mentioned, depends on geographic growing region, the stages of plant growth, collecting season, habitats and of climate conditions. As the maintenance of the thymol in the T. serpyllum essential oil in our research made nearly $50 \%$, that studying of its properties is of, in our opinion, undoubted interest.

Thymol (2-Isopropyl-5-methylphenol $-\mathrm{C}_{10} \mathrm{H}_{14} \mathrm{O}$ ) - organic substance, a natural monoterpene phenol derivative of cymene included in the composition of the essential oils of plants (Fig. 2).

In our study, thymol was the component of essential oil, which contained for almost half (41.8\%) of the weight of T. serpyllum. Currently, there are a sufficient number of published data on the cytotoxic effect of thymol on different types of cancer cells.

Lee K. et al. had shown, that thymol in vitro at concentrations up to $30 \mu \mathrm{M}$ did not affect the viability of C6 glioma cells), but approximately two times reduced their relative movability. An increase of thymol concentration up to $100 \mu \mathrm{M}$ induced the death of $20 \%$ of cells, and $200 \mu \mathrm{M}$ of thymol caused the death of $50 \%$ of the cells (19).

In Korean research works the thymol at the concentration of $100 \mu \mathrm{M}$ after $6 \mathrm{~h}$ led to the death of about $10 \%$ of cells of human gastric adenocarcinoma. After $24 \mathrm{~h}$, its effect was stable, but after $6 \mathrm{~h}$ at




Table 1. Relative percentage composition of the T. serpyllum L. essential oils.

\begin{tabular}{|c|c|c|c|}
\hline No & $\begin{array}{l}\text { Retention } \\
\text { time (min) }\end{array}$ & Compound & $\begin{array}{c}\text { Relative } \\
\text { content, \% }\end{array}$ \\
\hline 1 & 4.165 & Methyl isovalerate & 0.2 \\
\hline 2 & 4.205 & Methyl ester of 2-methyl-Butanoic acid & 0.1 \\
\hline 3 & 5.97 & 2-Hexenal & 0.1 \\
\hline 4 & 10.354 & $\beta$-Thujene & 1.3 \\
\hline 5 & 10.647 & $\alpha$-Pinene & 1.0 \\
\hline 6 & 11.297 & Camphene & 1.0 \\
\hline 7 & 12.929 & $\beta$-Pinene & 0.4 \\
\hline 8 & 13.135 & 1-Octen-3-ol & 1.1 \\
\hline 9 & 14.279 & $\beta$-Myrcene & 1.6 \\
\hline 10 & 14.859 & $\alpha$-Phellandrene & 0.3 \\
\hline 11 & 15.384 & 3-Carene & 0.1 \\
\hline 12 & 16.301 & o-Cymene & 10.9 \\
\hline 13 & 16.341 & m-Cymene & 1.8 \\
\hline 14 & 16.605 & Eucalyptol & 1.9 \\
\hline 15 & 16.767 & D-Limonene & 0.4 \\
\hline 16 & 18.37 & cis- $\beta$-Ocimene & 0.4 \\
\hline 17 & 19.379 & $\gamma$-Terpinene & 15.3 \\
\hline 18 & 19.423 & cis-Sabinene hydrate & 0.3 \\
\hline 19 & 21.143 & Terpinolene & 0.2 \\
\hline 20 & 22.145 & Linalool & 2.3 \\
\hline 21 & 25.274 & 2-Bornanone & 0.2 \\
\hline 22 & 26.65 & endo-Borneol & 2.5 \\
\hline 23 & 27.721 & Terpinen-4-ol & 0.9 \\
\hline 24 & 28.231 & Methyl salicylate & 0.2 \\
\hline 25 & 28.635 & Terpinen-4-ol & 0.3 \\
\hline 26 & 29.893 & p-Cymen-8-ol & 0.4 \\
\hline 27 & 32.828 & 3-Methoxy-p-cymene & 0.6 \\
\hline 28 & 38.793 & Thymol & 41.8 \\
\hline 29 & 39.45 & Carvacrol & 2.4 \\
\hline 30 & 42.348 & Thymol acetate & 0.1 \\
\hline 31 & 45.867 & $\beta$-Bourbonene & 0.1 \\
\hline 32 & 48.534 & Caryophyllene & 1.0 \\
\hline 33 & 50.009 & Aromandendrene & 0.3 \\
\hline 34 & 53.057 & $\gamma$-Muurolene & 0.5 \\
\hline 35 & 54.415 & Alloaromadendrene & 0.5 \\
\hline 36 & 54.899 & $\alpha$-Muurolene & 0.1 \\
\hline 37 & 55.688 & $\gamma$-Cadinene & 0.2 \\
\hline 38 & 56.15 & $\beta$-Bisabolene & 2.2 \\
\hline 39 & 56.686 & Cadina-1(10),4-diene & 0.4 \\
\hline 40 & 59.628 & Spathulenol & 0.2 \\
\hline 41 & 59.778 & trans-Nerolidol & 0.5 \\
\hline \multicolumn{3}{|c|}{$\begin{array}{ll} & \text { Total identified } \\
\end{array}$} & 96.1 \\
\hline
\end{tabular}


the concentration of $400 \mu \mathrm{M}$, it led to the death of $30 \%$ of cells, and in $24 \mathrm{~h} 50 \%$ of cells died (20).

At a concentration of $100-600 \mu \mathrm{M}$ thymol was also phytotoxic to cells of human osteosarcoma (MG63) (21) and at 200-800 $\mu \mathrm{M}$ concentration, thymol was the reason of the death of human glioblastoma cells after induction of apoptosis (22).

$\mathrm{IC}_{50}$ of thymol for human lung carcinoma A 549 was $200 \mu \mathrm{M}$ (23). Thymol demonstrated the dosedependent cytotoxic effects on HL-60 cells after $24 \mathrm{~h}$ of exposure. However, thymol did not show any cytotoxic effect in normal human PBMC (24).

In our research, thymol had a highly toxic effect on the colorectal cancer cells - HCT-15. Based on the conducted studies, it was found that thymol at a concentration of $40 \mu \mathrm{M}$ reduced the number of living cancer cells by half $\left(\mathrm{IC}_{50}=40 \mu \mathrm{M}\right)$ and at a concentration of $125 \mu \mathrm{M}$ almost completely destroys the cancer cells (Fig. 3).

Thus, $T$. serpyllum has a great interest as a plant object with high antitumor effect for the treatment of colorectal cancer. Since, firstly, colorectal cancer<smiles>Cc1ccc(C(C)C)c(O)c1</smiles>

Figure 2. Thymol structure occupies a leading position in the incidence of cancer in Kazakhstan; secondly, there are sufficient resources of the T. serpyllum on the territory of Kazakhstan.

\section{The content of flavonoids and their anticancer activity}

Flavonoids represent a wide group of secondary metabolites of plants, which possess a variety of beneficial effects including antioxidant and antitumor properties.

Total flavonoid content in the ethanol extract of T. serpyllum was $1.51 \%$ of the dry weight of the plant material (Table 2). As it is represented in Table 2 , most of the flavonoids are apigenin-7-glucoside $(0.24 \%)$, and the content of luteolin is 6 times less $(0.039 \%)$, quercetin is 40 times $(0.006 \%)$.

Apigenin-7-glucoside and quercetin have also been detected in extracts of T. serpylum, growing in Romania, but their content was much less, $3.9 \mu \mathrm{g} / \mathrm{g}$ and $6.58 \mu \mathrm{g} / \mathrm{g}$, respectively (7).

Recent studies have shown that ŕpigenin-7-glucoside $(15-60 \mu \mathrm{M})$ exhibited significant anti-proliferative activity against B16F10 melanoma cells. The percentage of apoptotic cells increased from 5\% (control) to $43 \%$ (in $60 \mu \mathrm{M}$ of apigenin-7-glucoside) after $48 \mathrm{~h}$ of exposure (25). In addition, apigenin-7-glucoside inhibited HL-60 leukemia cells growth, dose- and time-dependently, but it did not cause apoptosis (26).

In our researches apigenin in a concentration of 5 to $15 \mu \mathrm{M}$ reliably decreased the content of living cancer cells of HCT-15 (reduces by almost 17\%); further increase in the concentration of apigenin up to $125 \mu \mathrm{M}$ caused the death of cancer cells by only

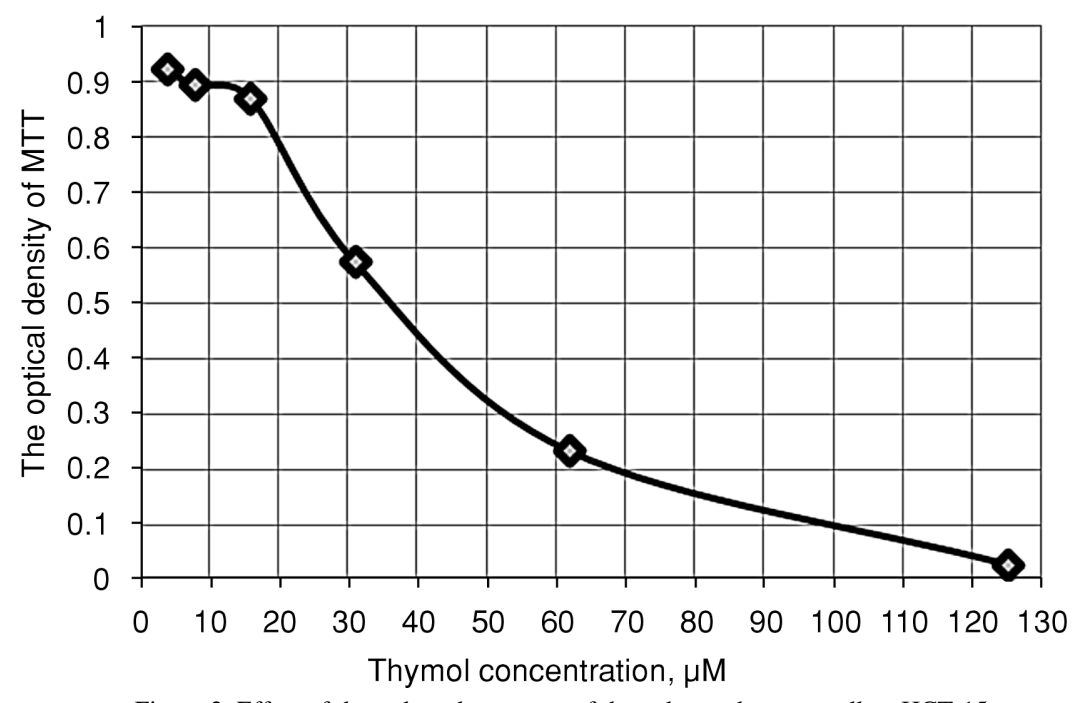

Figure 3. Effect of thymol on the content of the colorectal cancer cells - HCT-15 
Table 2. The content of the T. serpyllum flavonoids.

\begin{tabular}{|l|c|}
\hline \multicolumn{1}{|c|}{ Flavonoids } & The content in a dry plant, $\mathrm{mg} / \mathrm{g}$ \\
\hline The total content of all flavonoids & $15.1 \pm 0.65$ \\
\hline Apigenin 7 glucoside & $2.4 \pm 0.12$ \\
\hline Luteolin & $0.39 \pm 0.02$ \\
\hline Quercetin & $0.06 \pm 0.003$ \\
\hline
\end{tabular}

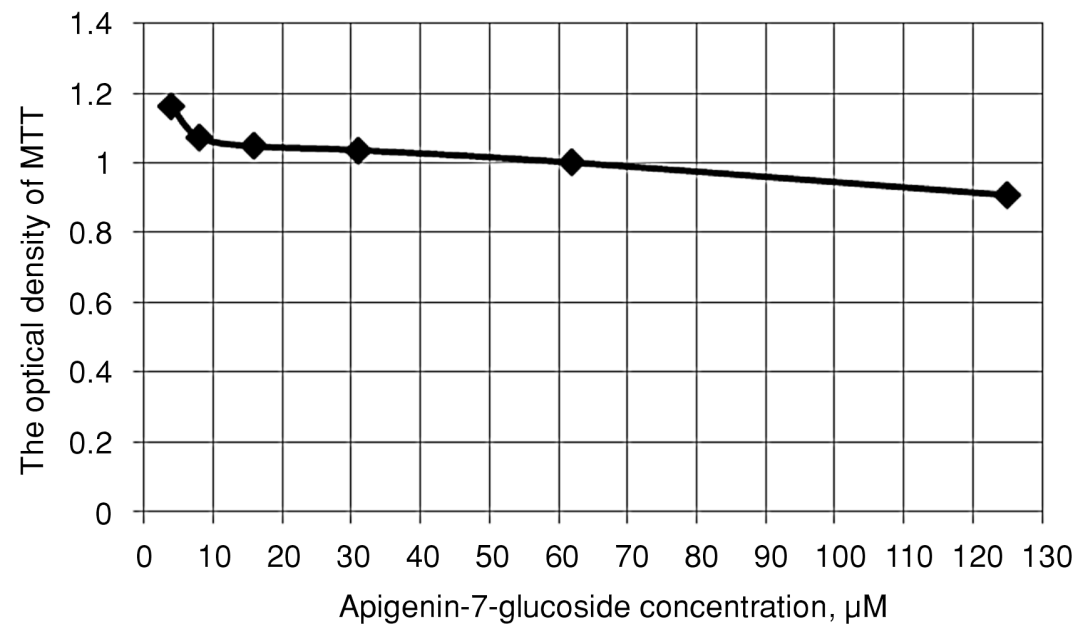

Figure 4. Effect of apigenin-7-glucoside on the content of the colorectal cancer cells - HCT-15

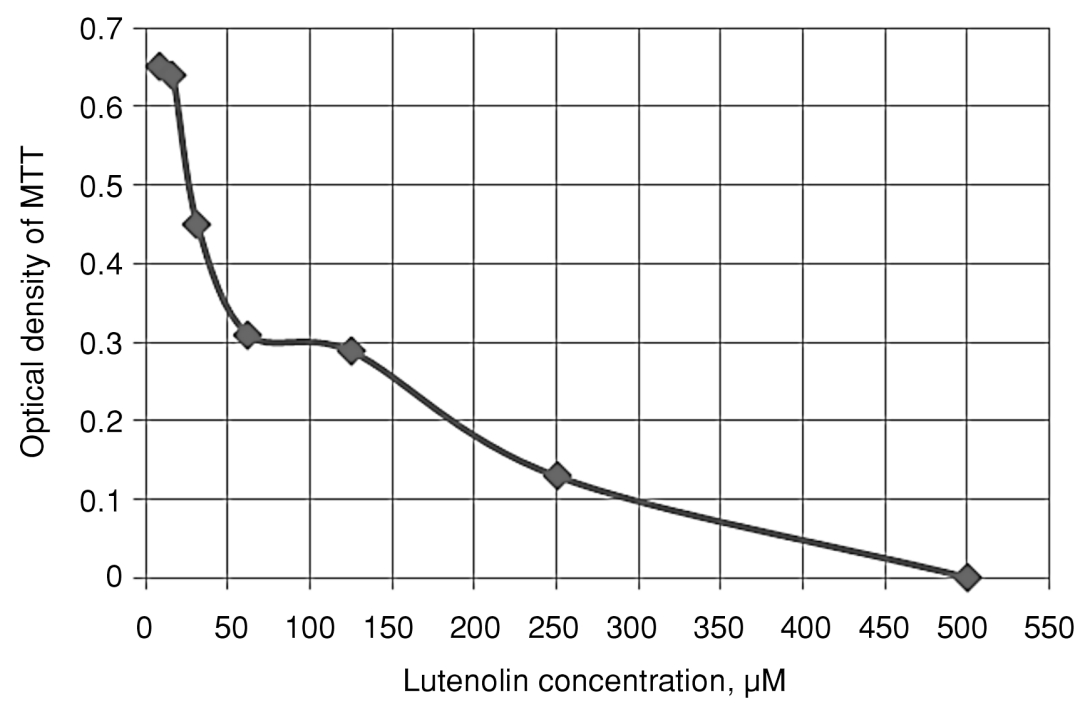

Figure 5. The effect of the luteolin on the content of the colorectal cancer cells - HCT-15

$8 \%$ (Fig. 4). Whereas thymol at a concentration of $125 \mu \mathrm{M}$ almost completely destroys the cancer cells (see Fig. 3).

According to the literature, it is known that plant flavonoids - luteolin, as well as quercetin, inhibit in vitro proliferation activity of cancer cells: MCF-7 and T-47D (27). Pretreatment of cells with 11-19 $\mu \mathrm{M}$ of either flavonoid - apigenin or luteolin, for $24 \mathrm{~h}$ resulted in $59-73 \%$ growth inhibition of pancreatic cancer cells (28). 


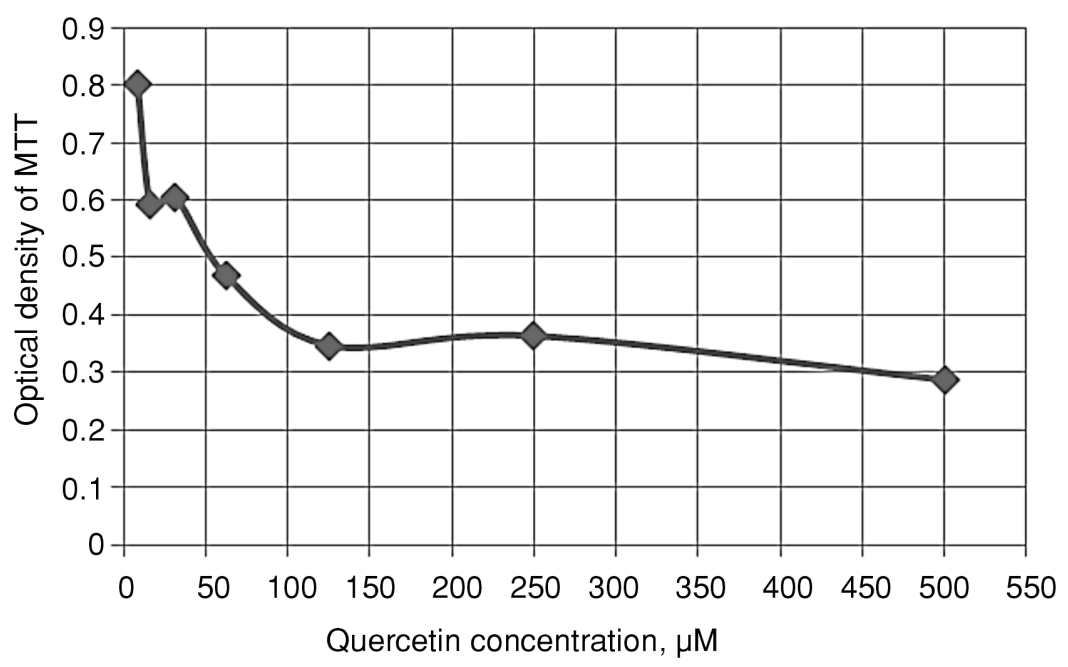

Figure 6. The effect of quercetin on the content of the colorectal cancer cells - HCT-15

In our studies luteolin, as well as quercetin, inhibit in vitro viability of HCT-15 - colon cancer cells (Fig. 3 and 4).

As the seen in Figure 5, the luteolin concentration of half-maximal inhibition of cancer cell growth $\left(\mathrm{IC}_{50}\right)$ was $50 \mu \mathrm{M}$ (decrease of MTT optical density from 0.65 to 0.32 ).

Our data are consistent with the reports of other investigators, who found that luteolin has a greater cytotoxic effect on other cancer cells. For instance, luteolin inhibited cell proliferation and increased apoptotic body formation in A2058 melanoma cells. The $\mathrm{IC}_{50}$ value of luteolin (35 $\mu \mathrm{g} / \mathrm{mL}$ ) was determined by the MTT assay (29). Luteolin suppressed also the prostate cancer cell proliferation in a dose-dependent manner in vitro and inhibited tumor growth in a xenograft model via induction of apoptosis and down-regulation of glutathione peroxidase 2 (30). Luteolin in the complex with oxidovanadium (IV) exhibited high viability inhibition $\left(\mathrm{IC}_{50}=17 \mu \mathrm{M}\right)$ against MDAMB231 breast cancer and A549 lung cancer cell lines (31). Luteolin induces apoptosis even in multidrug-resistant cancer cells (32). The $\mathrm{IC}_{50}$ value of quercetin was higher - $100 \mu \mathrm{M}$ (Fig. 6).

Thus, of all three studied flavonoids: luteolin, apigenin, and quercetin, luteolin showed the greatest cytotoxic effect against cells of colorectal cancer HCT-15. Luteolin at a concentration of $50 \mu \mathrm{m}$ caused $50 \%$ inhibition of cancer cells. Increasing the concentration of luteolin to $500 \mu \mathrm{m}$ caused the $100 \%$ of mortality of HCT-15 (colon cancer cells) (Fig. 5), where- as at the same concentration of quercetin $(500 \mu \mathrm{M})-$ $37.5 \%$ of the cancer cells were alive (Fig. 6). The least cytotoxic effect was shown by apigenin. The increase in its concentration to $125 \mu \mathrm{m}$ caused a decrease in the content of living cancer cells by only $25 \%$.

\section{CONCLUSION}

In the essential oil of the T. serpyllum, grown in the Southern Altai of the East Kazakhstan region, thymol was identified as the major oil constituent (41.8\% of the total content of essential oils). In addition, in the ethanol extract of T. serpyllum were also identified some flavonoids such as apigenin-7-glucoside, luteolin, quercetin. In addition, the content of luteolin $(1.11 \mathrm{mg} / \mathrm{g})$, which has the greatest anticancer effect among the three flavonoids found, was insignificantly higher than the content of thymol $(0.8 \mathrm{mg} / \mathrm{g})$. However, the anticancer effect of thymol was significantly higher than the anticancer action of luteolin.

A comparative analysis of our experimental data on the anticarcinogenic effect of thymol, apigenin-7-glucoside, luteolin, and quercetin on colorectal cancer cells (HCT-15) showed that thymol had the greatest cytotoxic effect. The cytotoxic effect of the studied substances was reduced in a row: thymol $\left(\mathrm{IC}_{50}=40 \mu \mathrm{M}\right)>$ luteolin $\left(\mathrm{IC}_{50}=50\right.$ $\mu \mathrm{M})>$ quercetin $\left(\mathrm{IC}_{50}=100 \mu \mathrm{M}\right)>$ apigenin-7-glucoside ( $\mathrm{IC}_{50}$ was not detected).

Thus, our data indicate the potential use of T. serpyllum as a vegetable raw material in the pro- 
duction of functional food products for prevention of colorectal cancer.

\section{Supporting information}

This research was supported by the Ministry of Education and Science of the Republic of Kazakhstan under National applied Research Project "The development of biotechnological methods of using herbs with antitumor effect in production of fermented milk products" (UA4 / 3028).

\section{Acknowledgments}

We would like to express our deepest gratitude to Associate professor A.R. Opekun and PhD T. E. Shaiken from Department of Medicine, Baylor College of Medicine (Houston, TX, USA) for their help in conducting scientific research on HCT-15 cancer cells.

\section{Conflict of interest}

The authors declare no conflict of interest.

\section{REFERENCES}

1. Zharykbasova K.S., Tazabayeva K.A., Silybayeva B.M., Kunanbayeva N.S.: The actual directions of medicinal plants application in a food industry. (Monograph in Russian). Tengry, Semey 2013.

2. Jaric S., Mitrovic M., Pavlovic P.: Evid. Based Complement. Alternat. Med. 2015, 101978 (2015).

3. Petrovic S.S., Ristic M.S., Petrovic N.V., Lazic M.L. et al.: Hem. Ind. 68, 389 (2014).

4. Wesolowska A., Grzeszczuk M., Jadczak D., Nawrotek P. et al.: Not. Bot. Horti. Agrobo. 43, 432 (2015).

5. Kindl M., Blazekovic B., Bucar F., VladimirKnezevic S.: Evid. Based Complement. Aternat. Med. 2015, 403950 (2015).

6. Nikolić M., Glamočlija J., Ferreira I.C.F.R., Calhelha R.C. et al.: Ind. Crops Prod. 52, 183 (2014).

7. Varga E., Bardocz A., Belak A., Maraz A. et al.: Farmacia 63, 357 (2015).

8. Khudonogova E.G., Kiseleva T.V.: Sibirskiy Vestnik Selskohozyaystvennoy Nauki (in Russian), 7, 110 (2010).

9. Gamaunova A.P., Dmitriyeva A.A.: in Kazakhstan Flora, vol. 7, (in Russian), Pavlov N.V. Ed., pp. 445-461, Academy of Sciences of the
Kazakh S.S.R. Publishing house, Almata (1964).

10. In: State Pharmacopoeia of the Republic of Kazakhstan, vol. 1, (in Russian), Tulegenova A.U. Ed., pp. 230-233, Zhibek zholyi Publishing house, Almata (2008).

11. Berridge M.V., Herst P.M., Tan A.S.: Biotechnol. Annu. Rev. 11, 127 (2005).

12. Berdowska I., Zielinski B., Fecka I., Kulbacka J. et al.: Food Chem. 141, 1313 (2013).

13. Bozkurt E., Atmaca H., Kisim A., Uzunoglu S. et al.: Nutr. Cancer 64, 1245 (2012).

14. Berdowska I., Marcinkowska A., Zielinski B., Fecka I. et al.: Adv. Clin. Exp. Med. 16 (3), 361 (2007).

15. Bulut C., Altiok E., Bayraktar O., Ülkü S.: Acta Hort. 826, 111 (2009).

16. Celikel N., Kavas G.: Czech J. Food Sci. 26, 174 (2008).

17. Kirillov V., Stikhareva T., Mukanov B., Chebotkova N. et al.: J. Essent. Oil Bear. Pl. 19, 212 (2016).

18. Raal A., Paaver U., Arak E., Orav A.: Medicina (Kaunas) 40, 795 (2004).

19. Lee K., Kim J.-E., Park W.-H., Hong H.: Oncol. Lett. 11, 2619 (2016).

20. Kang S.H., Kim Y.S., Kim E.K., Hwang J.W. et al.: J. Microbiol. Biotechnol. 26, 28 (2016).

21. Chang H.T., Hsu S.S., Chou C.T., Cheng J.S. et al.: Pharmacology 88, 201 (2011).

22. Hsu S.S., Lin K.L., Chou C.T., Chiang A.J. et al.: Eur. J. Pharmacol. 670, 85 (2011).

23. Coccimiglio J., Alipour M., Jiang Z.-H., Gottardo C. et al.: Oxid. Med. Cell. Longev. 2016, 1404505 (2016).

24. Deb D.D., Parimala G., Saravana D.S., Chakraborty T.: Chem. Biol. Interact. 193, 97 (2011).

25. Bouzaiene N.N., Chaabane F., Sass A., ChekirGhedira L. et al.: Life Sci. 144, 80 (2016)

26. Nakazaki E., Tsolmon S., Han J., Isoda H.: Eur. J. Nutr. 52, 25 (2013).

27. Affifi F.U., Abu-Dahab R.: Nat. Prod. Res. 26, 878 (2012).

28. Johnson J.L., Gonzalez de Mejia E.: Food Chem. Toxicol. 60, 83 (2013).

29. Kim J.K., Kang K.A., Ryu Y.S., Piao M.J. et al.: Anticancer Res. 36, 2281 (2016).

30. Naiki T., Naiki-Ito A., Etani T., Iida K. et al.: J. Urology 195, 1096 (2016).

31. Naso L.G., Lezama L., Valcarcel M., Salado C. et al.: J. Inorg. Biochem. 157, 80 (2016).

32. Rao P.S., Satelli A., Moridani M., Jenkins M. et al.: Int. J. Cancer 130, 2703 (2012).

Received: 25.09. 2017 